Article

\title{
Nano-Formulations of Copper Species Coated with Sulfated Polysaccharide Extracts and Assessment of Their Phytotoxicity on Wheat (Triticum aestivum L.) Seedlings in Seed Germination, Foliar and Soil Applications
}

\author{
Hanaa L. Essa ${ }^{1,2, *(\mathbb{C}, \text { Mohamed S. Abdelfattah }}{ }^{3}\left(\mathbb{D}\right.$, Alaa S. Marzouk ${ }^{2}$, Hania A. Guirguis ${ }^{1}(\mathbb{C}$ and \\ Mayyada M. H. El-Sayed ${ }^{1, *(1)}$ \\ 1 Chemistry Department, American University in Cairo, AUC Avenue, New Cairo 11835, Egypt; \\ Haniaguirguis@aucegypt.edu \\ 2 Pesticides Phytotoxicity Department, CAPL, Agriculture Research Centre, Dokki, Giza 12627, Egypt; \\ Alaamarzouk68@yahoo.com \\ 3 Natural Products Research Unit (NPRU), Chemistry Department, Faculty of Science, Helwan University, \\ Ain Helwan, Cairo 11795, Egypt; Mabdelfattah@science.helwan.edu.eg \\ * Correspondence: Hanaa@aucegypt.edu (H.L.E.); Mayyada@aucegypt.edu (M.M.H.E.-S.); \\ Tel.: +20-1069-255-158 (H.L.E.); +20-122-536-0530 (M.M.H.E.-S.)
}

Received: 14 August 2020; Accepted: 7 September 2020; Published: 10 September 2020

\begin{abstract}
Copper nanoparticles were synthesized via a bioreduction using sulfated polysaccharides (SPs) extracted from Avicennia marina mangrove leaves and their phytotoxicity effect on wheat (Triticum aestivum L.) seedlings was assessed. As analyzed by high-performance liquid chromatography (HPLC), SPs extract constituted mainly $49.3 \%$ glucose, $24.6 \%$ galactose and $20.5 \%$ glucouronic acid by mol. A nanoformulation of ultrafine $\mathrm{Cu}_{2} \mathrm{O} / \mathrm{Cu}(\mathrm{OH})_{2}$ nanoparticles coated with SPs ( $\mathrm{Cu}$ NPs) was prepared with an average particle size of $2.11 \pm 0.64 \mathrm{~nm}$ and a slightly negatively-charged zeta potential of $11 \pm 0.46 \mathrm{mV}$. Applying high concentrations of $\mathrm{Cu}$ NPs on wheat seeds inhibited the respective shoot and root relative growth percentages, yielding $13.22 \pm 9.91$ and $36.72 \pm 18.51 \%$ at $0.06 \mathrm{mg} / \mathrm{mL}$ of the nanoformulation. Comparable values were obtained when the seeds were subjected to $0.06 \mathrm{mg} / \mathrm{L}$ of SPs extract applied in the free form. In a foliar application, $0.06 \mathrm{mg} / \mathrm{mL}$ of $\mathrm{Cu}$ NPs reduced the respective total chlorophyll and carotenoids contents by $17.4 \%$ and $24.3 \%$ relative to the control while the treatment with SPs reduced them by slightly higher values of $27.9 \%$ and $32.6 \%$, respectively, after 14 days of application. Therefore, Cu NPs show a comparable inhibition effect to that of the free SPs extract but offer the additional advantages of nanoformulations. In soil applications, however, $\mathrm{Cu}$ NPs stimulated the growth of wheat seedlings in contrary to SPs and increased the total chlorophyll and carotenoids by $49.76 \%$ and $70 \%$, respectively. This gives an additional merit to the nanoformulation that can potentially be used as an effective biostimulant in soil.
\end{abstract}

Keywords: mangrove leaves; sulfated polysaccharides; copper nanoparticles; seed germination; phytotoxicity; wheat seedlings

\section{Introduction}

Marine polysaccharides are the main constituents of cell walls in seaweeds, or exoskeletons in crustaceans [1]. They are characterized by their linkage to sulfate ester groups and this distinguishes them from polysaccharides derived from terrestrial plants. The structure of marine polysaccharides depends on the type of species, its geographic origin, growth stage, and extraction method [2]. 
A previous study on water-soluble sulfated polysaccharides (SPs) extracted from Codium fragile revealed that they consisted of D-galactose, L-arabinose, and D-xylose in respective molar ratios of 2:2:1, along with traces of uronic acid and L-rhamnose [3]. In a different study, SPs separated from Ulva lactuca in aqueous medium constituted L-rhamnose, D-xylose, and D-glucose in molar ratios of approximately 4.2:1.3:1.0, respectively, together with $24 \%$ of D-glucuronic acid, $19 \%$ of ester sulfate and some traces of D-mannose [4]. In addition, sargassan obtained from Sargassum linifolium contained D-glucuronic acid, D-galactose, D-mannose, D-xylose, L-fucose, in respective molar proportions of 4.57:8.40:1.00:2.48:2.50 [5]. Different conventional and modern techniques have been utilized for the extraction of marine polysaccharides from seaweeds. An ultrasound-assisted extraction was utilized to obtain $44.8 \mathrm{~g} / \mathrm{Kg}$ of polysaccharides from the green algae Chlorella pyrenoidosa at optimal conditions of $400 \mathrm{~W}$ of ultrasound power, with an incubation in water at $100^{\circ} \mathrm{C}$ for $4 \mathrm{~h}$ followed by a precipitation of polysaccharides with $80 \%$ ethanol [6]. In another study, the optimal yield of polysaccharides was obtained from the green algae Ulva lactuca using an ultrasound-assisted extraction at $60^{\circ} \mathrm{C}$ for $4 \mathrm{~h} \mathrm{[7]}$.

The growth of plants and their response to environmental impacts entail modifications in the processes of metabolism, photosynthesis, gene expression and regulation of plant hormone levels. Plant hormones control all aspects of growth and development as well as immune responses. For example, ethylene and abscisic acid (ABA) act as plant growth inhibitors while cytokinins, auxin and gibberellins act as plant growth stimulators [8]. The role of these phytohormones was reported in previous work that applied different concentrations of glucose to Arabidopsis seedlings. After 7 days from glucose application, the primary root growth declined due to interactions between glucose and ABA [9].

Intensive agriculture encompasses the use of increased labor and capital to maximize productivity. It usually involves the utilization of fertilizers and heavy machinery. On the other hand, extensive agriculture relies on the natural circumstances of soil, rain and sunlight with minimal inputs of labor and capital. To increase productivity, it is mainly practiced in large areas of land where demand is moderate. Intensive agriculture provides more products per unit of land while extensive agriculture provides natural and less toxic products. So, while more productive, intensive agriculture is more inclined to cause environmental damage due to the use of chemicals and machinery which reduces soil quality $[10,11]$. Therefore, utilizing bio-based stimulants and inhibitors that originate from natural sources would be favored to mitigate the drawbacks of intensive agriculture.

Metal nanoparticles have been investigated for their phytotoxic effect on plants where they have been reported to act as either herbicides that inhibit plant growth or stimulants that promote growth. The effect of nanoparticles on plant growth depends on the type of plant, the means of nanoparticle application and the conditions of exposure. With the growing need for environmentally-friendly synthesis processes, the chemical methods for nanoparticle synthesis have been replaced with greener alternatives. Several studies reported the biosynthesis of $\mathrm{Cu}_{2} \mathrm{O} / \mathrm{Cu}(\mathrm{OH})_{2}$ nanoparticles $(\mathrm{Cu} N P s)$ from the crude marine algal extracts such as those of the green alga Botryococcus braunii [12], as well as those of the brown seaweeds of Bifurcaria bifurcate [13] and Sargassum polycystum [14]. The phytotoxicity of copper oxide nanoparticles was reported in different studies. Upon treatment with $600 \mathrm{mg} / \mathrm{L}$ of $\mathrm{CuO}$ NPs, the rate of germination of cucumber seeds was inhibited showing a low germination rate of $23.3 \%$. Root elongation tests confirmed that the $\mathrm{CuO}$ nano form is a stronger inhibitor than its bulk form [15]. Another study reported the inhibition of pigments content in rice seedlings exposed to $1000 \mathrm{mg} / \mathrm{L}$ of $\mathrm{CuO}$ [16]. The impacts of $\mathrm{CuO}$ nanoparticles on the germination and seedling development of Phaseolus vulgaris was found to be affected by the concentration and structure of the nanoparticles [17].

The present work adopts a low-cost, green and efficient approach for the synthesis of a core-shell nanoformulation composed of $\mathrm{Cu}$-based nanoparticles as the core and sulfated polysaccharide extracts as the shell. The nanoformulation will be prepared via a bioreduction of copper salts using SPs extracted from Avicennia marina mangrove leaves. Thus, it will be referred to as $\mathrm{Cu}$ NPs and will be characterized by ultraviolet-visible spectrophotometry, transmission electron microscopy and scanning electron microscopy. Afterward, the phytotoxicity of the nanoformulation will be evaluated in seed 
germination studies as well as in foliar and soil field applications on wheat plants (Triticum aestivum L.) which are commonly found in Egypt and worldwide. Other species exist elsewhere in the world like durum, compactum, macha, vavilovi and spharcrocoum. Previous studies reported the biosynthesis of copper oxide nanoparticles using crude extracts. Since polysaccharides are the main reductant in the crude extracts, SPs were extracted in the current study to be efficiently utilized for the bioreduction. This approach thus produced nanoformulations whereby the SPs are carried as a coating or stabilizing layer onto the copper nanoparticles, hence the phytotoxicity of these nanoformulations was compared to that of the SPs extracts when applied in the free form.

\section{Materials and Methods}

\subsection{Chemicals}

For the extraction of sulfated polysaccharides, ethanol (96\%) was purchased from the International Company for Supplies and Medical Industries (Giza, Egypt). For chemical analyses, phenol (BDH, England), sulfuric acid 98\% (Penta, Prague, Czech Republic) and Folin and Ciocalteu's phenol reagent (Loba Chemie, Colaba, Mumbai, India) were used. For nanoparticle synthesis, copper sulfate pentahydrate $\left(\mathrm{CuSO}_{4} \cdot 5 \mathrm{H}_{2} \mathrm{O}\right)$ was purchased from Anachemia Ltd. (Montreal, QC, Canada). For pot experiment, NPK fertilizer which constitutes (20/20/20) by weight (on dry basis) of nitrogen/phosphorus/potassium elements, was purchased from Misr El-Dawliya for Agricultural and Industrial Development Co. (Kwesna, Egypt) and dimethyl sulfoxide (DMSO) was purchased from Daejung Chemical and Metal Co., Ltd. (Siheung, Korea).

\subsection{Collection and Preparation of Mangrove Leaves}

The collection of fresh mangrove leaves (Avicennia marina (Forssk.) Vierh was conducted in winter 2017, where leaves were collected from Ras Mohammed National Park on the southern shore of Sinai (Aqaba Gulf). Voucher samples of the plant were recognized by Dr. Mohamed Massed Hejazi at the Botany Herbarium Laboratory of the Department of Marine Science, Suez Canal University, Ismailia, Egypt. Leaves were ground in an electric mortar, and the powdered samples were stored at $-20^{\circ} \mathrm{C}$.

\subsection{SPS Extraction}

In $100 \mathrm{~mL}$ of distilled water, $5 \mathrm{~g}$ of ground A. marina leaves were suspended and submerged for $15 \mathrm{~min}$ at room temperature (RT) in an ultrasonicator (Branson 2510 sonicator, model 2510DTH, Hampton, NH, USA), then filtered through a cheese cloth. The filtrate was dialyzed overnight in a dialysis bag (VISKING dialysis tubing: regenerated cellulose/MWCO 12,000-14,000 Da, pore diameter approx. $25 \mathrm{~A}^{\circ}$, SERVA Electrophoresis $\mathrm{GmbH}$, Heidelberg, Germany) after which it was centrifuged for $10 \mathrm{~min}$ at $-10^{\circ} \mathrm{C}$ and $5500-6000 \mathrm{rpm}$ (Heraeus-Christ, GMBH336 Osteode Ma Harz No.39189, Hanau, Germany). Afterward, the supernatant was collected and added to ethanol in the proportion of 1:3 $(v / v)$, respectively. Subsequent centrifugation under the same previously-mentioned conditions was carried out and the supernatant (SPs) was collected [7]. Extraction was performed in triplicate.

\subsection{Acid Hydrolysis of SPS}

SPs were subjected to hydrolysis before being analyzed via high-performance liquid chromatography (HPLC) according to the reported method [18]. Briefly, the hydrolysis was carried out by refluxing $0.5 \mathrm{~g}$ of each sample with $30 \mathrm{~mL}$ of $2 \mathrm{~N}$ sulfuric acid for $24 \mathrm{~h}$. At the end of the hydrolysis, the precipitate was filtered off. Then, the sulfate was removed from the filtrate by precipitation with barium carbonate. The hydrolysate of each sample was evaporated under vacuum using a rotary evaporator (Rotavap, Heidolph Laborota 4003 Control, Schwabach, Germany) to yield a residue, which was dried and extracted with hot distilled pyridine. Each pyridine extract was evaporated to dryness and the residues were preserved at $4{ }^{\circ} \mathrm{C}$ for further studies. 


\subsection{HPLC-RID Analysis of SPs Sugar Content}

The extracts of SPs and the standard samples were filtered through a $0.45 \mu \mathrm{m}$ membrane and injected in a volume of $20 \mu \mathrm{L}$ to be detected on a High Performance Liquid Chromatography-Refractive Index Detector (HPLC-RID). The analysis was conducted using HPLC, Shimadzu Class-VPV 5.03 (Kyoto, Japan) equipped with a refractive index RID-10A Shimadzu detector, LC-16ADVP binary pump and PL Hi-Plex Pb column, and a heater set at $80{ }^{\circ} \mathrm{C}$. The mobile phase was $0.01 \%$ reagent grade calcium chloride prepared with deionized water, while the flow rate was $0.6 \mathrm{~mL} \mathrm{~min}{ }^{-1}$. An analysis of the sugars in the filtrate was performed according to the previous literature [19].

\subsection{Synthesis of $\mathrm{Cu} N P s$}

A mass of $0.02 \mathrm{~g}$ of SPs was placed in $10 \mathrm{~mL}$ of distilled water in a $250 \mathrm{~mL}$ Erlenmeyer flask and then the mixture was added to a $100 \mathrm{~mL}$ solution of $3 \mathrm{mM}$ of copper sulfate pentahydrate $\left(\mathrm{CuSO}_{4} \cdot 5 \mathrm{H}_{2} \mathrm{O}\right)$. The solution was left stirring at $70^{\circ} \mathrm{C}$ for $3 \mathrm{~h}$ until its color changed from blue to green [20]. To confirm the formation of nanoparticles, an ultraviolet-visible (UV-Vis) spectrophotometer (Varian, Cary 500 Scan, Palo Alto, California, USA) was used to measure the wavelength of the produced nanoparticles. The nanoformulation was then centrifuged for $10 \mathrm{~min}$ at $-10^{\circ} \mathrm{C}$ and $5500-6000 \mathrm{rpm}$ (Heraeus-Christ, GMBH336 Osteode Ma Harz No. 39189, Hanau, Germany). Finally, the supernatant was dialyzed to remove unreacted copper sulfate.

\subsection{Characterization of SPs and $\mathrm{Cu} N \mathrm{NP}_{\mathrm{s}}$}

For Fourier Transform Infrared (FTIR) spectroscopic analysis, samples of SPs and Cu NPs were combined with potassium bromide to form pellets of $1 \mathrm{~mm}$. The analysis was performed using a Nicolet 380 Thermogravimetric Analysis/Fourier Transform Infrared (TGA/FTIR) spectrometer for a range of 500 to $4000 \mathrm{~cm}^{-1}$ wavenumbers. Additionally, an X-ray diffractometer with $\mathrm{Cu} \mathrm{K} \alpha$ radiation (Bruker D8 Discover, Karlsruhe, Germany) at a wavelength of $1.54 \mathrm{~A}^{\circ}$ was used to examine the phase and constitution of the prepared nanoparticle powders which were precipitated on a silicon holder. To study the morphology of Cu NPs, SEM (ZEISS- LEO SUPRA 55, Jena, Germany) was used to examine the surface structure of the synthesized nanoparticles. A fine gold coat was deposited on the samples under vacuum in a JFC-1100 sputter coater (JEOL) for $3 \mathrm{~min}$ at $15 \mathrm{~mA}$. TEM (Type JEOL-JEM-2100, Software: Gatan Digital Micrograph, Akishima, Tokyo, Japan) was also used to examine the nanosize of the particles. Specimens of several milligrams of powdered samples were suspended in distilled water and spread well for $15 \mathrm{~min}$ in an ultrasonic bath. The zeta potential of the synthesized nanoparticles was determined using Dynamic Light Scattering (DLS) measurements (Malvern Zeta Sizer, Nano ZS, Malvern, UK), with a helium-neon laser operating at a $90^{\circ}$ scattering angle and $633 \mathrm{~nm}$ wavelength at $25{ }^{\circ} \mathrm{C}$. The chemical composition of the synthesized nanoparticles was measured using a Bench Top SEM + EDX, JEOL, JCM 6000 plus (Akishima, Tokyo, Japan). The Energy-dispersive X-ray (EDX) spectroscopic conditions were $15 \mathrm{KV}$ with a working distance of $19 \mathrm{~mm}$.

\subsection{Chemical Analysis of SPs and $\mathrm{Cu} N P S$}

The total carbohydrate contents of SPs and Cu NPs were determined using the glucose-sulfuric technique described elsewhere [7]. Furthermore, the phenolic content was determined as outlined previously [21,22] using gallic acid as a standard [23].

\subsection{Seed Germination Test}

This test was performed to explore the seed germination and seedling growth effects of SPs and $\mathrm{Cu}$ NPs. Wheat crop seeds (Triticum aestivum L.) (monocotyledonous), an intensive cereal field crop of the cultivar of Sakha 93, were examined. These were obtained and classified at the Agricultural Research Centre (ARC) in Egypt. Sakha 93 was selected since it is the most common cultivar in Egypt, being widely used due to its ability to stand heat and water stress thus yielding high production. 
Experiments were carried out in triplicate, and in accordance with the American Society for Testing and Materials (ASTM, 2003) protocols with minor modifications [24]. Both SPs and Cu NPs were diluted with distilled water at serial concentrations of 0.00 (control), $0.002,0.004,0.03$ and $0.06 \mathrm{mg} / \mathrm{mL}$. Petri dishes of $10 \mathrm{~cm}$ diameter, containing Whatman filter paper No. 10, were utilized. Ten wheat seeds/dish were placed, and $3 \mathrm{~mL}$ of each concentration was added individually. The total samples of this test including replicates are $(10$ seeds/replicates $) \times 3=30$ sample/treatment, as each concentration is considered one treatment. All dishes were then incubated in the dark for 7 days in a Thermos Fisher incubator at $25 \pm 2{ }^{\circ} \mathrm{C}$. The root and shoot lengths were determined, while the relative germination rate (RGR), relative root and shoot elongation (RRE) and germination index (GI) were calculated relative to the control $[25,26]$ according to the following equations:

$$
\begin{gathered}
\mathrm{RGR}=\left[\frac{\text { Seeds germinated in examined sample }}{\text { seeds germinated in control }}\right] * 100 \\
\mathrm{RRE}=\left[\frac{\text { Mean root length in examined sample }}{\text { Mean root length in control }}\right] * 100 \\
\mathrm{GI}=\left[\frac{\mathrm{RGR} * \mathrm{RRE}}{100}\right]
\end{gathered}
$$

\subsection{Pot Experiment}

A Sakha 93 wheat plant (Triticum aestivum L.) was planted in silt clay soil (Table 1) during the winter season (2018/2019) and thinned to 5 seedlings per pot after 14 days of foliar or soil application. Irrigation was practiced maintaining the soil at almost its field capacity for the period of the growing season. During the experiment, NPK fertilizer was added to the pots at an average rate of $2 \mathrm{~g} / \mathrm{pot}$, after 15 days from seedling and the process was repeated weekly until the end of the experiment. Two application methods-foliar and soil treatment-were used for SPs and $\mathrm{Cu}$ NPs applications. The prepared concentrations of 0.00 (control), $0.004,0.03$ and $0.06 \mathrm{mg} / \mathrm{mL}$ of SPs and $\mathrm{Cu}$ NPs were applied individually using a treatment volume of 15 and $25 \mathrm{~mL}$ for foliar and soil

\begin{tabular}{|c|c|c|c|c|c|c|c|}
\hline \multicolumn{5}{|c|}{ Physical Properties } & $\mathrm{SP} * \%$ & $\mathrm{EC}^{* *}$ (m.mhos) & $\mathrm{pH}$ \\
\hline $\begin{array}{l}\text { Clay \% } \\
33.50\end{array}$ & $\begin{array}{l}\text { Silt } \% \\
35.60\end{array}$ & $\begin{array}{c}\text { Sand } \% \\
30.90\end{array}$ & $\begin{array}{l}\text { Total } \% \\
100.00\end{array}$ & $\begin{array}{l}\text { Texture } \\
\text { Silt clay }\end{array}$ & 50.00 & 3.85 & 7.93 \\
\hline
\end{tabular}
applications, respectively.

Table 1. Physical and chemical characteristics of the soil used in this study.

\begin{tabular}{lcccccccccc}
\hline \multicolumn{3}{c}{ Soluble cations (meq/L) } & \multicolumn{3}{c}{ Soluble anions (meq/L) } & \multicolumn{3}{c}{ Ppm } \\
\hline $\mathrm{Ca}^{++}$ & $\mathrm{Mg}^{++}$ & $\mathrm{Na}^{+}$ & $\mathrm{K}^{+}$ & $\mathrm{CO}_{3}^{--}$ & $\mathrm{HCO}_{3}^{-}$ & $\mathrm{Cl}^{-}$ & $\mathrm{SO}_{4}^{--}$ & $\mathrm{N}$ & $\mathrm{K}$ & $\mathrm{P}$ \\
\hline 10.20 & 6.70 & 19.90 & 0.90 & 0.0 & 1.90 & 33.20 & 2.90 & 66.0 & 236.2 & 0.61 \\
\hline
\end{tabular}

\subsection{Phytotoxicity Measurements}

\subsubsection{Chlorophyll and Carotenoids Contents}

The procedure reported by Hiscox and Israelstam [27] was used with minor modifications. After 7 and 14 days from planting, $10 \mathrm{mg}$ of unground fresh leaves were placed in a test tube containing $5 \mathrm{~mL}$ of dimethyl sulfoxide (DMSO). Chlorophyll was extracted into the fluid at $55^{\circ} \mathrm{C}$ by incubating in the dark overnight. Absorbance (A) or optical density (O.D.) was measured using a spectrophotometer (Spectronic 20) at 644 and $662 \mathrm{~nm}$ for chlorophyll (a) and (b), respectively, and at $470 \mathrm{~nm}$ for carotenoids. The total chlorophyll, chlorophyll (a), and chlorophyll (b) contents were calculated using Arnon 
equations (Equations (4)-(6)) [28], while the Cañal equation (Equation (7)) [29] was used for estimating the carotenoids content.

$$
\begin{gathered}
\text { Chl.a }=12.7 \times \text { O.D. } 662-2.69 \times \text { O.D. } 644 \mathrm{mg} / \mathrm{L} \\
\text { Chl.b }=22.9 \times \text { O.D. } 644-4.68 \times \text { O.D. } 662 \mathrm{mg} / \mathrm{L} \\
\text { Chl. } \mathrm{a}+\mathrm{b}=20.2 \times \text { O.D. } 644+8.02 \times \text { O.D.662 mg } / \mathrm{L} \\
\text { Carotenoids }=(\mathrm{A} 470-1.28(\mathrm{chl} . \mathrm{a} \mathrm{mg} / \mathrm{L})+56.7(\mathrm{chl} . \mathrm{b} \mathrm{mg} / \mathrm{L})) /(256 \times 0.906) \mathrm{mg} / \mathrm{L}
\end{gathered}
$$

\subsubsection{Dry Weight and Total Phenolic Content}

At the end of the experiment (after 45 days from planting), the total wheat plants/pot (5 plants) were collected and dried at $60^{\circ} \mathrm{C}$ for $48 \mathrm{~h}$ (until stability of weight). The dry matter content was recorded using a Mettler Toledo balance AL204. The total phenolic content of wheat leaves was determined using the Folin-Ciocalteu reagent in the same manner as mentioned in Section 2.7.

\subsection{Statistical Analysis}

The statistical analysis was performed using SPSS version 20 for Windows (SPSS Inc., USA). A one-way analysis of variance (ANOVA) was conducted to test the significant differences $(p<0.05)$ between the treatment and control means. Duncan's multiple range test (DMRT) was also performed to determine the significant differences between the tested groups.

A summary of the work conducted in this study is outlined in Figure 1.

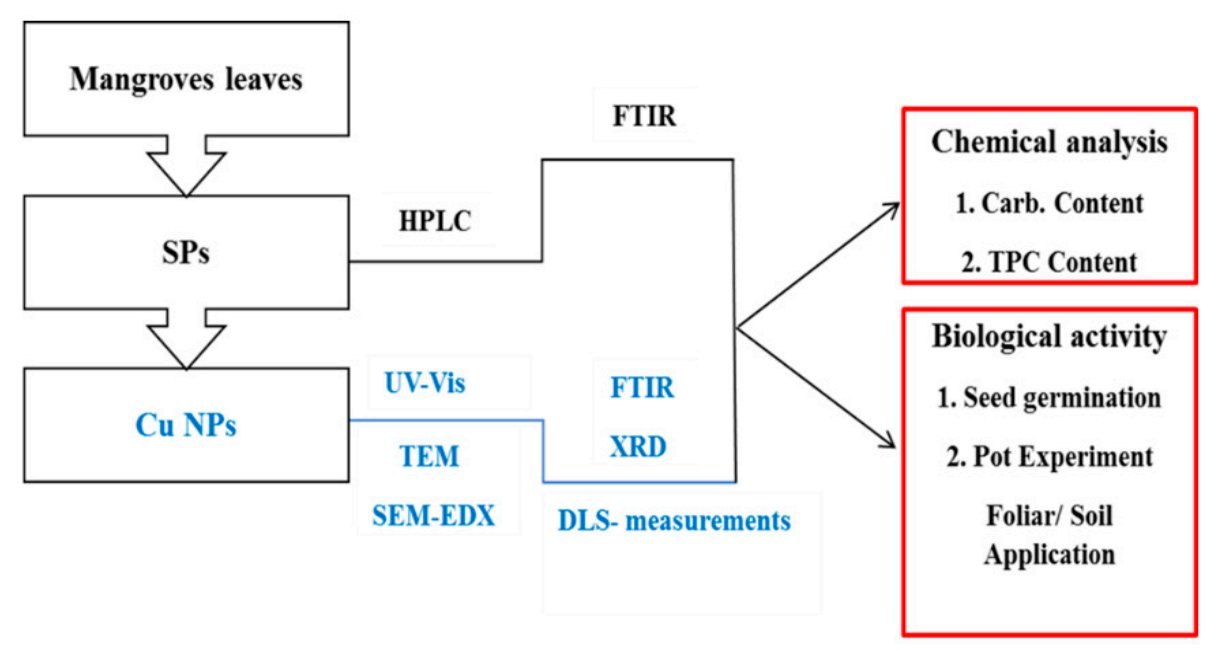

Figure 1. Schematic outline of the work conducted in this study.

\section{Results and Discussion}

A yield of $3.52 \% \pm 0.94$ SPs was obtained from mangrove leaves. It constituted $44 \% \pm 0.01$ carbohydrates, and had a phenolic content of $50.62 \% \pm 0.1 \mathrm{mgGA} / \mathrm{g}$. As for the biosynthesized Cu NPs, they constituted $3.3 \% \pm 0.004$ carbohydrates and $1.44 \% \pm 0.1 \mathrm{mgGA} / \mathrm{g}$. The presence of carbohydrate and phenolic contents in $\mathrm{Cu}$ NPs could be owed to the formation of the SPs capping layer that coats the $\mathrm{Cu}$ NPs. As analyzed by HPLC, the SPs extract was mainly comprised of $49.3 \%$ glucose, $24.6 \%$ galactose and $20.5 \%$ glucouronic acid by mol (Table S1 and Figure S1).

To confirm the formation of Cu NPs, UV-Vis spectroscopy and TEM imaging were used. Figure 2a demonstrates the UV-visible spectrum of $\mathrm{Cu}$ NPs where an absorbance peak appears at the range of 250-350 nm. A similar range was reported in the previous literature for $\mathrm{Cu}$ NPs biosynthesized using gooseberry fruits [30] and Vitis vinifera leaves [31]. In Figure 2b, the TEM micrographs show regular spheres with an average diameter of approximately $2.11 \pm 0.64 \mathrm{~nm}$. Larger sized copper oxide 
nanoparticles of dimensions 5-45 $\mathrm{nm}$ have been synthesized from brown alga (Bifurcaria bifurcata) as reported in the previous literature [13]. In addition, the SEM images in Figure $2 \mathrm{~d}$ reveal homogenous and spherical particles, with an elemental composition of $54.97 \% \mathrm{O}, 19.20 \% \mathrm{C}, 13.64 \% \mathrm{~S}$ and $12.18 \%$ $\mathrm{Cu}$ by mass as analyzed by EDX (Figure 2c). DLS measurements showed that the produced Cu NPs are slightly negative in charge with a zeta potential of $11 \pm 0.46 \mathrm{mV}$ at the working $\mathrm{pH}$ range of 6-7. This charge aids to reduce the agglomeration between the $\mathrm{Cu}$ NPs and it could be attributed to the SPs functional groups present in the coating layer.
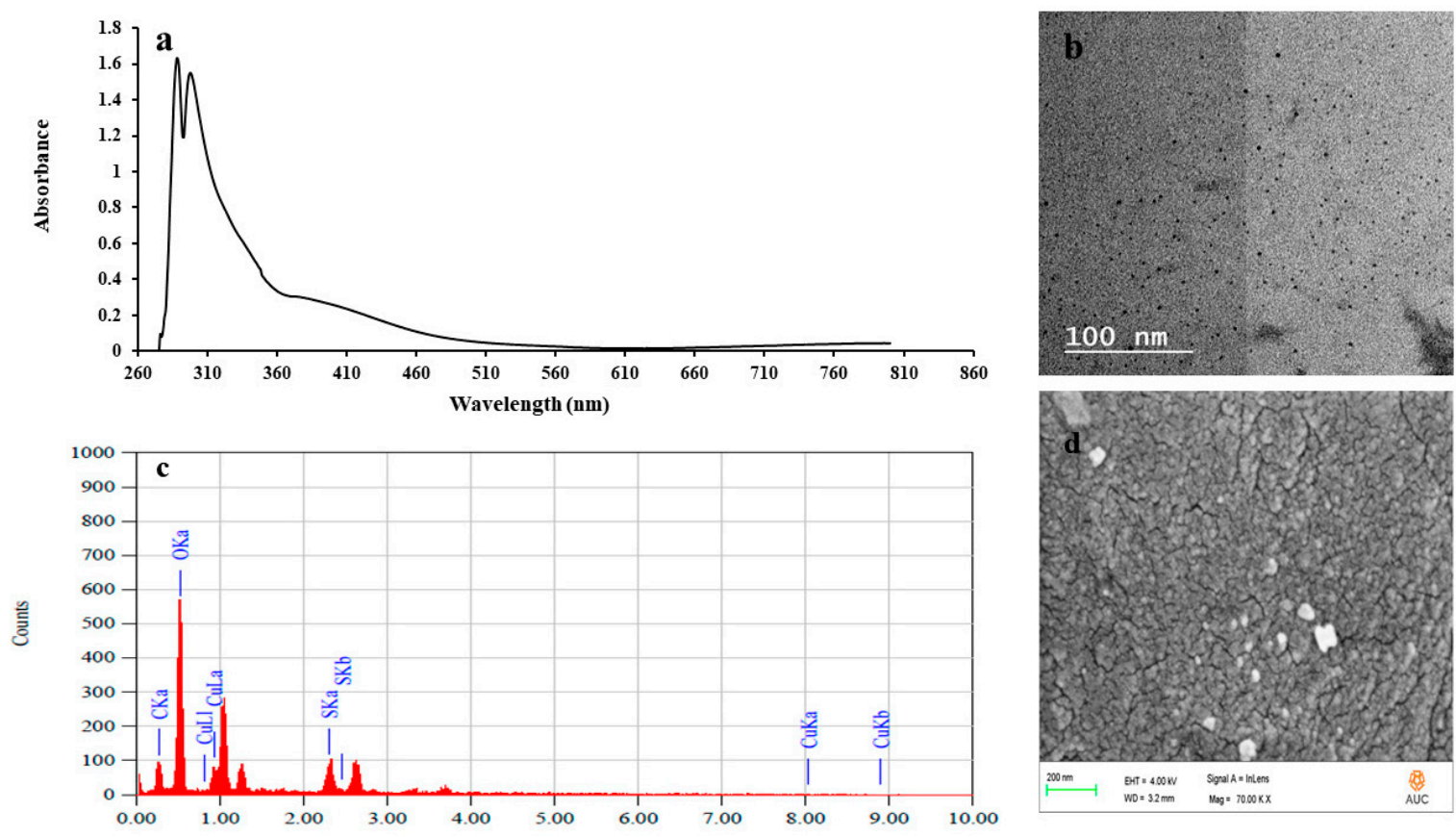

Figure 2. Characterization of sulfated polysaccharides (SPs) and $\mathrm{Cu}_{2} \mathrm{O} / \mathrm{Cu}(\mathrm{OH})_{2}$ nanoparticles $(\mathrm{Cu} N P s)$ using ultraviolet-visible (UV-Vis) spectroscopy (a), Transmission Electron Microscopy (TEM) imaging (b), Elemental-dispersive (EDX) spectroscopy analysis (c) and Scanning Electron Microscopy (SEM) imaging $(\mathbf{d})$.

The XRD pattern for the produced Cu NPs is depicted in Figure 3a, where major peaks at about $12^{\circ}, 19.5^{\circ}$ and $23.5^{\circ}$ could be observed. The $12^{\circ}$ peak could be ascribed to $\mathrm{Cu}(\mathrm{OH})_{2}$, while the latter two peaks could be attributed to $\mathrm{Cu}_{2} \mathrm{O}$. In addition, minor peaks at $32^{\circ}, 37^{\circ}$ and $45^{\circ}$ appeared and could also be assigned to $\mathrm{Cu}_{2} \mathrm{O}$. Hence, the observed peaks could indicate the presence of two main $\mathrm{Cu}$ species [32,33], the orthorhombic phase of $\mathrm{Cu}(\mathrm{OH})_{2}$ (JCPDS: \#80-0656), and the cubic phase of $\mathrm{Cu}_{2} \mathrm{O}$ (ICCD-JCPDS: \#78-2076) which correspond to the lattice planes of (020), (021), (111) and (200), respectively. According to the Pourbaix diagram, copper would predominantly be present in the form of $\mathrm{Cu}$ (I) species at $\mathrm{pH}$ 6-7 (solution $\mathrm{pH}$ ).

The FTIR spectra of SPs and Cu NPs are presented in Figure 3b. Both SPs and Cu NPs show bands at wavelengths of $3400,1625,1450-1420$ and $1109 \mathrm{~cm}^{-1}$ that correspond to the stretching vibration of the hydroxyl $(\mathrm{O}-\mathrm{H})$ group, the bending vibration of $\mathrm{C}-\mathrm{O}$ of uronic acids, $(\mathrm{S}=\mathrm{O})$ sulfate ester bonds and acidic polysaccharides, respectively [34,35]. These functional groups are bound to the surface of the $\mathrm{Cu}$ NPs and act as stabilizing agents. 


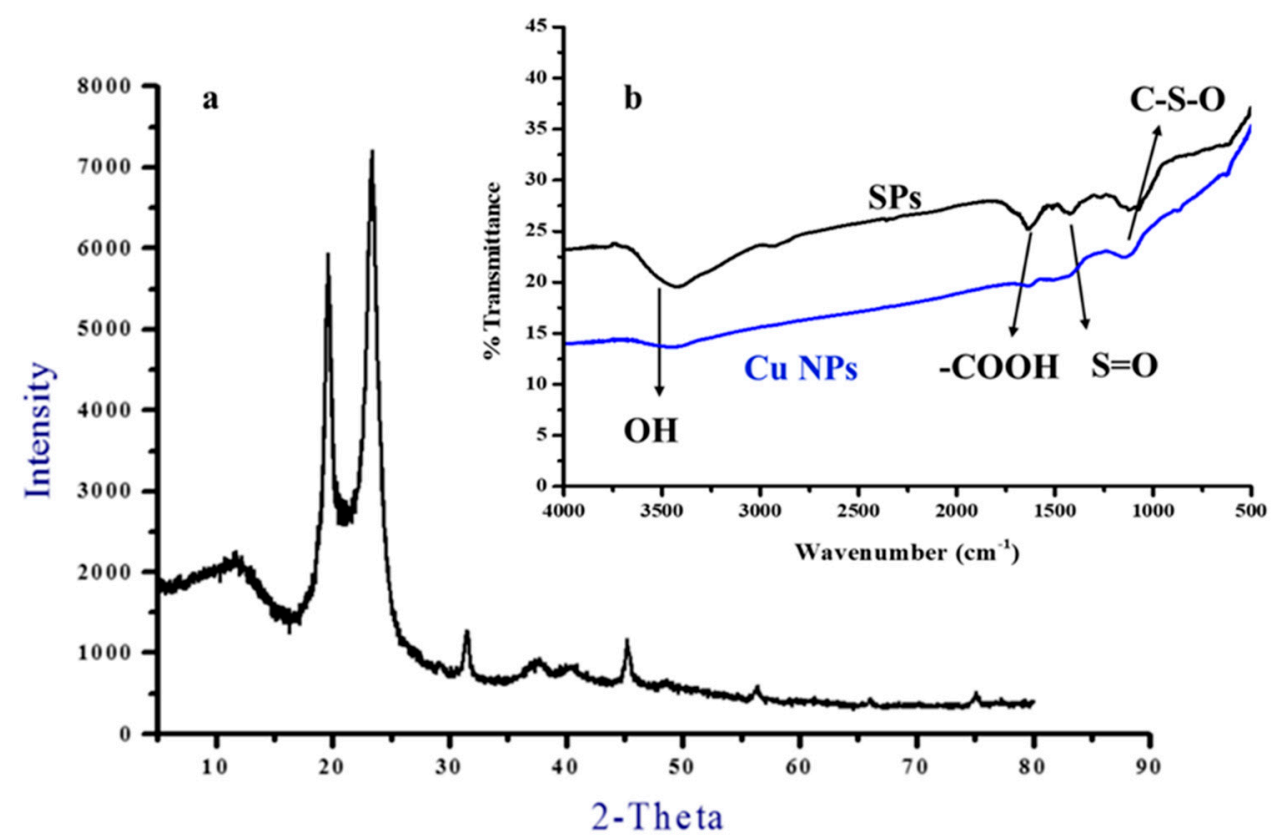

Figure 3. XRD pattern (a) of Cu NPs and FTIR spectra (b) of SPs and Cu NPs.

\subsection{Impact on Seed Germination}

\subsubsection{Shoot and Root Length}

The effect of different concentrations of SPs and Cu NPs on the root and shoot lengths of the germinated wheat seeds is depicted in Table 2.

Table 2. Effect of SPs and Cu NPs on root and shoot lengths $(\mathrm{cm})$ of wheat seedlings.

\begin{tabular}{|c|c|c|c|}
\hline \multirow{2}{*}{\multicolumn{2}{|c|}{ Concentration $(\mathrm{mg} / \mathrm{mL})$}} & \multicolumn{2}{|c|}{ Wheat } \\
\hline & & \multirow{2}{*}{$\begin{array}{c}\begin{array}{c}\text { Average Shoot } \\
\text { Length (cm) }\end{array} \\
2.67^{\mathrm{a}} \pm 0.72\end{array}$} & \multirow{2}{*}{$\begin{array}{c}\begin{array}{c}\text { Average Root } \\
\text { Length (cm) }\end{array} \\
3.78^{\mathrm{a}} \pm 1.32\end{array}$} \\
\hline Untreated & 0.00 & & \\
\hline \multirow{4}{*}{ SPs } & 0.002 & $0.99^{b} \pm 0.86$ & $2.65^{b} \pm 1.20$ \\
\hline & 0.004 & $0.88^{b c} \pm 0.79$ & $2.47^{b} \pm 1.11$ \\
\hline & 0.03 & $0.45^{\mathrm{d}} \pm 0.21$ & $2.41^{b} \pm 0.83$ \\
\hline & 0.06 & $0.37^{d} \pm 0.22$ & $1.58^{\mathrm{c}} \pm 0.74$ \\
\hline \multicolumn{2}{|c|}{ Mean of treatment } & 0.67 & 2.27 \\
\hline \multirow{4}{*}{$\mathrm{Cu}$ NPs } & 0.002 & $0.55^{c d} \pm 0.43$ & $2.34^{b} \pm 0.91$ \\
\hline & 0.004 & $0.52^{\mathrm{cd}} \pm 0.50$ & $2.10^{b c} \pm 1.31$ \\
\hline & 0.03 & $0.46^{\mathrm{d}} \pm 0.24$ & $2.02^{b c} \pm 0.44$ \\
\hline & 0.06 & $0.35^{\mathrm{d}} \pm 0.26$ & $1.39^{c} \pm 0.70$ \\
\hline \multicolumn{2}{|c|}{ Mean of treatment } & 0.47 & 1.96 \\
\hline \multicolumn{2}{|c|}{ LSD } & 0.47 & 0.75 \\
\hline
\end{tabular}

Figures followed by the same letters are insignificant.

Upon the exposure of wheat seeds to either SPs or Cu NPs, a significant reduction can be observed in their shoot and root lengths as compared to the untreated control at all tested concentrations. For SPS exposure, the highest reduction in the shoot and root length was observed at the concentration of $0.06 \mathrm{mg} / \mathrm{mL}$ where the shoot and root length were recorded to be $0.37 \pm 0.22$ and $1.58 \pm 0.74 \mathrm{~cm}$, respectively. Exposure of wheat seeds to $\mathrm{Cu}$ NPs revealed a clear insignificant dose-dependent effect with respective shoot and 
root lengths of $0.35 \pm 0.26$ and $1.39 \pm 0.70 \mathrm{~cm}$ obtained at $0.06 \mathrm{mg} / \mathrm{mL}$. These results indicate that SPs and $\mathrm{Cu}$ NPs have comparable inhibitory effects on the shoot and root lengths of wheat seeds.

\subsubsection{Relative Growth (\%)}

Data pertaining to the percentage relative wheat shoot and root growth are shown in Table 3, where it can be deduced that they both decreased gradually with increasing the concentration of either SPs or Cu NPs. Their lowest values were obtained at the concentration of $0.06 \mathrm{mg} / \mathrm{mL}$ where SPs showed a percentage relative growth of $13.88 \pm 8.24$ and $41.86 \pm 19.82 \%$, while $\mathrm{Cu}$ NPs recorded comparable values of $13.22 \pm 9.91$ and $36.72 \pm 18.51 \%$ for the wheat shoot and root, respectively. This implies that both SPs and $\mathrm{Cu}$ NPs have a negative impact on root and shoot growth and their highest inhibition effects were attained at $0.06 \mathrm{mg} / \mathrm{mL}$. In addition, the germination index order (combined seed germination and root elongation) for the tested concentrations of SPs and Cu NPs was as follows: SPs $0.004>$ SPs $0.002>$ SPs $0.03>$ NPs $0.002>$ NPs $0.004>$ NPs $0.03>$ SPs $0.06>$ NPs 0.06 .

Table 3. Effect of SPs and Cu NPs on percentage relative growth of shoot and root lengths, germination rate and germination index of wheat seed.

\begin{tabular}{|c|c|c|c|c|c|}
\hline \multirow[t]{2}{*}{ Treatment } & \multirow{2}{*}{$\begin{array}{c}\text { Conc. } \\
(\mathrm{mg} / \mathrm{mL})\end{array}$} & \multicolumn{2}{|c|}{$\begin{array}{l}\% \text { Relative Growth of Wheat Shoot and } \\
\text { Root Length }\end{array}$} & \multirow[t]{2}{*}{ Relative GR \% * } & \multirow[t]{2}{*}{$\mathrm{GI} * *$} \\
\hline & & Shoot & Root & & \\
\hline \multirow{4}{*}{ SPs } & 0.002 & $37.01^{a} \pm 32.29$ & $70.03^{a} \pm 31.80$ & 103.6 & 72.62 \\
\hline & 0.004 & $33.05^{a} \pm 29.82$ & $65.36^{a} \pm 29.60$ & 107.1 & 74.23 \\
\hline & 0.03 & $16.96^{\mathrm{b}} \pm 7.95$ & $63.65^{\mathrm{a}} \pm 22.04$ & 100 & 62.43 \\
\hline & 0.06 & $13.88^{b} \pm 8.24$ & $41.86^{\mathrm{bc}} \pm 19.82$ & 100 & 41.01 \\
\hline \multirow{4}{*}{$\mathrm{Cu}$ NPs } & 0.002 & $20.71^{b} \pm 16.38$ & $61.78^{a} \pm 24.24$ & 96.4 & 59.67 \\
\hline & 0.004 & $19.61^{b} \pm 18.84$ & $55.56^{\mathrm{ab}} \pm 34.72$ & 96.4 & 53.55 \\
\hline & 0.03 & $17.18^{b} \pm 9.27$ & $53.38^{a b c} \pm 11.72$ & 100 & 53.17 \\
\hline & 0.06 & $13.22^{b} \pm 9.91$ & $36.72^{\mathrm{c}} \pm 18.51$ & 100 & 36.77 \\
\hline
\end{tabular}

The negative effect of $\mathrm{Cu}$ NPs on seed germination and growth was also observed with silver nanoparticles that were applied to 11 species of wetland plants [36], while the reduction in the germination index with an increasing concentration of $\mathrm{Cu}$ NPs was also reported in previous work on wheat seeds [37], which is in agreement with our study.

The results of seed germination studies (Table 3) also revealed that the application of low concentrations of SPs slightly enhanced the relative germination rate in wheat relative to the control. The application of low concentrations of $\mathrm{Cu}$ NPs, on the other hand, reduced the germination rate relative to the control. This inhibitory effect was previously observed in studies where the effects of copper nanoparticles and ZnO NPs on the germination percentage of wheat and corn seeds were individually investigated, respectively [38,39]. At the highest concentration of $0.06 \mathrm{mg} / \mathrm{L}$, both SPs and $\mathrm{Cu}$ NPs had the same effect on the germination rate. This behavior is consistent with the shoot and root relative growth results discussed earlier.

The inhibitory effects of SPs and $\mathrm{Cu}$ NPs on seed germination can be owed to their glucose content since it is the major component present in SPs constituting $49.3 \%$ by mol as detected by HPLC analysis. This has been previously evidenced in the literature since plant glucose was shown to affect many processes, including germination, early seedling growth, flowering and senescence [40,41]. A genetic analysis revealed that sugar signaling in plants is closely related to plant hormone biosynthesis and signaling, in particular to the hormone of abscisic acid, ABA [42,43]. The sugar mediated delay in germination was explained through the inhibitory role of the plant hormone ABA, and the stimulatory effects of Gibberellic acid (GA) and ethylene [44]. 


\subsection{Assessment of Phytotoxicity}

\subsubsection{Foliar Application}

Table 4 shows the contents of chlorophyll a, b, total chlorophyll and carotenoids in wheat leaves upon their treatment with a foliar application of SPs and $\mathrm{Cu}$ NPs. As clear from the table and for SPs, chlorophyll (a) decreased significantly compared to the control upon increasing the SPs concentration to $0.06 \mathrm{mg} / \mathrm{mL}$, recording 3.61 and $4.90 \mathrm{mg} / \mathrm{g}$ fresh weight after 7 and 14 days from application, respectively. Upon the exposure of wheat leaves to $0.06 \mathrm{mg} / \mathrm{mL}$ of $\mathrm{Cu}$ NPs, chlorophyll (a) decreased insignificantly relative to the control, recording $4.10 \mathrm{mg} / \mathrm{g}$ fresh weight after 7 days from application. However, it significantly decreased after 14 days from application, recording a fresh weight of $5.68 \mathrm{mg} / \mathrm{g}$ at the highest concentration of $0.06 \mathrm{mg} / \mathrm{mL}$. This indicates that the inhibitory effect of Cu NPs on chlorophyll (a) could only be realized at the highest employed concentration and only after 14 days.

Chlorophyll (b) followed the same behavior as chlorophyll (a), where its content decreased with increasing the concentration of SPs to $0.06 \mathrm{mg} / \mathrm{mL}$ and recorded respective fresh weight values of 2.82 and $4.06 \mathrm{mg} / \mathrm{g}$ after 7 and 14 days of applying SPs, respectively. Meanwhile, treatment with Cu NPs showed no significant effect on the chlorophyll (b) content except after 14 days of applying $0.06 \mathrm{mg} / \mathrm{mL}$ of the nanoformulation which resulted in a fresh weight of $4.60 \mathrm{mg} / \mathrm{g}$ of chlorophyll (b).

In addition, total chlorophyll decreased significantly relative to the control upon increasing the concentration of SPs and $\mathrm{Cu}$ NPs to $0.06 \mathrm{mg} / \mathrm{mL}$, recording 8.96 and 10.28 after 14 days of application, respectively. Similar trends have been reported in previous studies which examined the effect of $1 \mathrm{mg} / \mathrm{L}$ of $\mathrm{CuO}$ nanoparticles on total chlorophyll content, chlorophyll (a) and (b) of Arabidopsis thaliana seedlings [45] and Elsholtzia splendens [46]. Additionally, in agreement with the current results are those obtained from studies conducted on Ag nanoparticles. In these studies, the effect of Ag nanoparticles $(20 \mathrm{~nm}$ ) was investigated on the photosynthetic pigments (chlorophyll a and b) of Coriandrum sativum when exposed to a nanoparticle concentration of $800 \mathrm{mg} / \mathrm{L}$ [47], in addition to those of $V$. radiata and B. campestris seedlings upon their exposure to silver nanoparticles at a concentration of $1000 \mu \mathrm{g} / \mathrm{mL}$ [48], as well as those of Arabidopsis thaliana and Dracocephalum moldavica plants when treated with $3 \mathrm{mg} / \mathrm{L}$ and $80 \mathrm{mg} / \mathrm{L}$ of Ag nanoparticles, respectively [49,50]. The seeds of Arabidopsis thaliana were commonly tested in the above studies since they represent a good model for determining the growth parameters, as they grow relatively faster and have a shorter life cycle than other species [45].

Carotenoids followed a similar trend to that of the total chlorophyll after 14 days of SPs or Cu NPs application since it significantly decreased relative to the control when the concentration of either SPs or $\mathrm{Cu}$ NPs increased to $0.06 \mathrm{mg} / \mathrm{mL}$. Under these conditions, the carotenoids content decreased when compared to the control and recorded 0.97 and $1.09 \mathrm{mg} / \mathrm{g}$ fresh weight upon treatment with SPs and $\mathrm{Cu}$ NPs, respectively. This behavior resembles that previously reported for the effect of silver nanoparticles $(47 \mathrm{~nm})$ on the carotenoids content of mustard (Brassica sp.) seedlings [51]. After 7 days of application of $0.06 \mathrm{mg} / \mathrm{mL}$ of either SPs or Cu NPs, an insignificant decrease in the carotenoids content was, however, observed. 
Table 4. Chlorophyll and carotenoids contents ( $\mathrm{mg} / \mathrm{g}$ fresh weight) in wheat leaves exposed to a foliar application of SPs and Cu NPs.

\begin{tabular}{|c|c|c|c|c|c|c|c|c|c|}
\hline & & \multicolumn{4}{|c|}{ Chlorophyll } & \multicolumn{2}{|c|}{ Total Chlorophyll $(a+b)$} & \multicolumn{2}{|c|}{ Carotenoids } \\
\hline \multirow{2}{*}{\multicolumn{2}{|c|}{$\begin{array}{c}\text { Concentration } \\
\mathrm{mg} / \mathrm{mL}\end{array}$}} & \multicolumn{2}{|c|}{7 DFA * } & \multicolumn{2}{|c|}{14 DFA } & \multirow{2}{*}{7 DFA } & \multirow{2}{*}{14 DFA } & \multirow{2}{*}{7 DFA } & \multirow{2}{*}{14 DFA } \\
\hline & & $\mathbf{a}$ & $\mathbf{b}$ & a & $\mathbf{b}$ & & & & \\
\hline \multirow{4}{*}{ SPs } & Cont. & $4.34^{\mathrm{a}} \pm 0.07$ & $3.42^{\mathrm{ab}} \pm 0.04$ & $6.40^{a} \pm 0.14$ & $6.04^{a} \pm 0.35$ & $7.76^{\mathrm{a}} \pm 0.11$ & $12.44^{b} \pm 0.49$ & $0.81^{\mathrm{ab}} \pm 0.01$ & $1.44^{\mathrm{a}} \pm 0.09$ \\
\hline & 0.004 & $3.94^{\mathrm{abc}} \pm 0.17$ & $3.07^{a b c} \pm 0.19$ & $6.03^{b} \pm 0.27$ & $5.27^{b} \pm 0.52$ & $7.01^{b} \pm 0.36$ & $11.30^{c} \pm 0.24$ & $0.73^{a b} \pm 0.05$ & $1.26^{b} \pm 0.13$ \\
\hline & 0.03 & $3.82^{b c} \pm 0.41$ & $2.87^{b c} \pm 0.56$ & $5.93^{b} \pm 0.03$ & $5.05^{b c} \pm 0.02$ & $6.69^{b c} \pm 0.15$ & $10.98^{c} \pm 0.05$ & $0.68^{b} \pm 0.14$ & $1.20^{b c} \pm 0.01$ \\
\hline & 0.06 & $3.61^{c} \pm 0.27$ & $2.82^{\mathrm{c}} \pm 0.23$ & $4.90^{\mathrm{d}} \pm 0.05$ & $4.06^{\mathrm{d}} \pm 0.07$ & $6.43^{c} \pm 0.50$ & $8.96^{\mathrm{e}} \pm 0.12$ & $0.67^{b} \pm 0.06$ & $0.97^{\mathrm{d}} \pm 0.02$ \\
\hline \multirow{3}{*}{$\mathrm{Cu}$ NPs } & 0.004 & $4.31^{\mathrm{a}} \pm 0.06$ & $3.49^{\mathrm{a}} \pm 0.13$ & $6.38^{a} \pm 0.03$ & $5.94^{\mathrm{a}} \pm 0.00$ & $7.80^{\mathrm{a}} \pm 0.19$ & $12.32^{b} \pm 0.03$ & $0.83^{a} \pm 0.03$ & $1.42^{\mathrm{a}} \pm 0.00$ \\
\hline & 0.03 & $4.22^{\mathrm{ab}} \pm 0.16$ & $3.32^{a b c} \pm 0.15$ & $6.54^{\mathrm{a}} \pm 0.01$ & $6.40^{\mathrm{a}} \pm 0.07$ & $7.54^{\mathrm{a}} \pm 0.31$ & $12.94^{\mathrm{a}} \pm 0.06$ & $0.79^{a b} \pm 0.04$ & $1.53^{\mathrm{a}} \pm 0.02$ \\
\hline & 0.06 & $4.10^{\mathrm{ab}} \pm 0.35$ & $2.94^{\mathrm{abc}} \pm 0.46$ & $5.68^{c} \pm 0.19$ & $4.60^{c} \pm 0.30$ & $7.04^{b} \pm 0.11$ & $10.28^{d} \pm 0.11$ & $0.69^{\mathrm{ab}} \pm 0.11$ & $1.09^{\mathrm{c}} \pm 0.07$ \\
\hline \multicolumn{2}{|c|}{ LSD } & 0.486 & 0.546 & 0.346 & 0.533 & 0.500 & 0.496 & 0.133 & 0.126 \\
\hline
\end{tabular}

* DFA: days from application. 
From the above, it can be deduced that the treatment of wheat plants with $0.06 \mathrm{mg} / \mathrm{mL}$ of either SPs or Cu NPs significantly reduced the total chlorophyll and carotenoids contents relative to the control after 14 days of application. This reflects the inhibitory effects of both SPs and Cu NPs on plant growth. However, the inhibitory effect of SPs was slightly more pronounced than that of $\mathrm{Cu}$ NPs since treatment with SPs reduced the respective total chlorophyll and carotenoids contents by $27.9 \%$ and $32.6 \%$ relative to the control, whereas the treatment with $\mathrm{Cu}$ NPs reduced them by $17.4 \%$ and $24.3 \%$, respectively. This behavior is slightly different than that observed in seed germination where the inhibitory effects of SPs and $\mathrm{Cu}$ NPs were comparable. The pathways of $\mathrm{Cu}$ NPs uptake or absorption in seed germination where the nanoparticles can easily cross the cell membrane is different from its pathway in foliar applications where metal penetration can take place via the stomatal pores of the leaves. The transport of $\mathrm{Cu}$ NPs into the leaves might have thus been governed by diffusional resistances that were slightly less encountered during the transport of SPs which are free in solution [52,53]. Despite the slightly higher inhibitory effect shown by SPs relative to $\mathrm{Cu}$ NPs, their effects could still be considered comparable since the reduction in total chlorophyll and carotenoids contents upon treatment with SPs exceed that obtained with $\mathrm{Cu}$ NPs by no more than $10 \%$ as is clear from the values given above.

\subsubsection{Soil Application}

Table 5 shows the contents of chlorophyll a, b, total chlorophyll and carotenoids in wheat leaves exposed to each of SPs and Cu NPs via a soil application. By inspecting the data pertaining to SPs treatment, it can be deduced that chlorophyll (a) decreased relative to the control yielding $2.13 \mathrm{mg} / \mathrm{g}$ fresh weight at the concentration of $0.06 \mathrm{mg} / \mathrm{mL} 14$ days after application. However, no significant difference in chlorophyll (a) content was observed after 7 days of application. On the contrary, treatment with $\mathrm{Cu}$ NPs significantly increased the chlorophyll (a) content recording 2.59 and $5.13 \mathrm{mg} / \mathrm{g}$ fresh weight at $0.06 \mathrm{mg} / \mathrm{mL}$ after 7 and 14 days from application, respectively.

Chlorophyll (b) followed a rather different behavior to that of chlorophyll (a) upon soil exposure to either SPs or $\mathrm{Cu}$ NPs after 7 days of application, but a similar behavior after 14 days of application. With SPs treatments, chlorophyll (b) decreased significantly as compared to the control yielding 1.46 and $1.44 \mathrm{mg} / \mathrm{g}$ fresh weight after 7 and 14 days from the application of $0.06 \mathrm{mg} / \mathrm{mL}$ SPs, respectively. The treatment with $\mathrm{Cu}$ NPs, on the other hand, increased the content to $4.26 \mathrm{mg} / \mathrm{g}$ fresh weight after 14 days from the application of $0.06 \mathrm{mg} / \mathrm{mL}$. However, no significant change in chlorophyll (b) content was observed after 7 days from the application of the same concentration of $\mathrm{Cu}$ NPs. Thus, eventually after 14 days of application, both chlorophyll (a) and (b) decreased upon treatment with SPs, whereas they both increased when subjected to $\mathrm{Cu}$ NPs treatment. Chlorophyll (a), therefore, followed the same behavior as chlorophyll (b) since the latter has been reported to prevent chlorophyll (a) from degradation during the photosynthesis process. 
Table 5. Contents of chlorophyll and carotenoids ( $\mathrm{mg} / \mathrm{g}$ fresh weight) of wheat leaves exposed to a soil application of SPs and Cu NPs.

\begin{tabular}{|c|c|c|c|c|c|c|c|c|c|}
\hline & & \multicolumn{4}{|c|}{ Chlorophyll } & \multicolumn{2}{|c|}{ Total Chlorophyll $(a+b)$} & \multicolumn{2}{|c|}{ Carotenoids } \\
\hline \multirow{2}{*}{\multicolumn{2}{|c|}{$\begin{array}{c}\text { Concentration } \\
\mathrm{mg} / \mathrm{mL}\end{array}$}} & \multicolumn{2}{|c|}{7 DFA * } & \multicolumn{2}{|c|}{14 DFA } & \multirow{2}{*}{7 DFA } & \multirow{2}{*}{14 DFA } & \multirow{2}{*}{7 DFA } & \multirow{2}{*}{14 DFA } \\
\hline & & $\mathbf{a}$ & $\mathbf{b}$ & $\mathbf{a}$ & $\mathbf{b}$ & & & & \\
\hline \multirow{3}{*}{ SPs } & 0.004 & $2.80^{b} \pm 0.19$ & $1.94^{\mathrm{a}} \pm 0.03$ & $2.95^{d} \pm 0.06$ & $2.10^{d} \pm 0.07$ & $4.74^{b} \pm 0.22$ & $5.05^{d} \pm 0.13$ & $0.45^{\mathrm{a}} \pm 0.01$ & $0.50^{\mathrm{d}} \pm 0.02$ \\
\hline & 0.03 & $2.34^{\mathrm{cd}} \pm 0.22$ & $1.63^{b} \pm 0.12$ & $2.70^{\mathrm{e}} \pm 0.04$ & $1.92^{\mathrm{e}} \pm 0.07$ & $3.97^{\mathrm{d}} \pm 0.34$ & $4.62^{\mathrm{e}} \pm 0.11$ & $0.39^{b} \pm 0.03$ & $0.45^{\mathrm{e}} \pm 0.02$ \\
\hline & 0.06 & $2.20^{\mathrm{d}} \pm 0.01$ & $1.46^{b} \pm 0.05$ & $2.13^{f} \pm 0.00$ & $1.44^{\mathrm{f}} \pm 0.01$ & $3.66^{d} \pm 0.05$ & $3.57^{\mathrm{f}} \pm 0.01$ & $0.34^{b} \pm 0.01$ & $0.34^{\mathrm{f}} \pm 0.00$ \\
\hline \multirow{3}{*}{ Cu NPs } & 0.004 & $2.14^{\mathrm{d}} \pm 0.04$ & $1.50^{b} \pm 0.05$ & $2.96^{d} \pm 0.07$ & $2.21^{\mathrm{d}} \pm 0.14$ & $3.64^{d} \pm 0.01$ & $5.17^{\mathrm{d}} \pm 0.21$ & $0.35^{b} \pm 0.01$ & $0.52^{\mathrm{d}} \pm 0.04$ \\
\hline & 0.03 & $3.74^{a} \pm 0.20$ & $2.20^{a} \pm 0.12$ & $4.07^{b} \pm 0.03$ & $3.02^{b} \pm 0.11$ & $5.94^{a} \pm 0.33$ & $7.9^{b} \pm 0.08$ & $0.52^{a} \pm 0.03$ & $0.72^{b} \pm 0.03$ \\
\hline & 0.06 & $2.59^{b c} \pm 0.25$ & $1.93^{a} \pm 0.24$ & $5.13^{a} \pm 0.04$ & $4.26^{\mathrm{a}} \pm 0.01$ & $4.52^{b c} \pm 0.49$ & $9.39^{a} \pm 0.05$ & $0.45^{\mathrm{a}} \pm 0.06$ & $1.02^{\mathrm{a}} \pm 0.00$ \\
\hline \multicolumn{2}{|c|}{ LSD } & 0.370 & 0.263 & 0.253 & 0.186 & 0.483 & 0.440 & 0.063 & 0.046 \\
\hline
\end{tabular}

* DFA: days from application. 
Carotenoids decreased significantly with an increasing concentration of SPs, recording $0.34 \mathrm{mg} / \mathrm{g}$ fresh weight after 7 days of treatment with $0.06 \mathrm{mg} / \mathrm{mL}$ SPs, while no change was observed in total chlorophyll content at that concentration of SPs. Both the total chlorophyll and carotenoids decreased significantly with an increasing concentration of SPs recording respective contents of 3.57 and $0.34 \mathrm{mg} / \mathrm{g}$ fresh weight after 14 days of treatment with $0.06 \mathrm{mg} / \mathrm{mL}$ of SPs. An opposite trend can be seen upon an application of $\mathrm{Cu}$ NPs for 14 days, since they both increased with an increasing $\mathrm{Cu}$ NPs concentration to $0.06 \mathrm{mg} / \mathrm{mL}$, recording a 9.39 and $1.02 \mathrm{mg} / \mathrm{g}$ fresh weight, respectively. This corresponds to a 49.76 and $70 \%$ increase in the contents of total chlorophyll and carotenoids, respectively. However, no effect on either the total chlorophyll or carotenoids content was observed after 7 days of application, as was previously encountered with chlorophyll (b). Previous studies reported an increase in the carotenoids content of Dracocephalum moldavica when exposed to Ag NPs $(10 \mathrm{~nm})$ at a concentration of $80 \mathrm{mg} / \mathrm{L}$ after 21 days from the application of Ag NPs [50], as well as an increase in chlorophyll (a) and the total chlorophyll contents of rocket (Eruca sativa) upon exposure to $\mathrm{Fe}_{3} \mathrm{O}_{4}$ nanoparticles $(25 \mathrm{~nm}$ ) at concentrations of 1 and $2 \mathrm{mg} / \mathrm{L}$ after 5 weeks from the application [54]. The stimulating effect of $\mathrm{Cu}$ NPs in soil applications is contradictory to the inhibitory effect encountered in foliar applications. This can be owed to the different pathways by which $\mathrm{Cu}$ NPs uptake or absorption onto plants can occur. Foliar uptake involves adsorption and internalization via the cuticle and then penetration of metals via stomatal pores. The metals are thus transported inside the plants from the aerial parts towards the different plant organs (roots, flowers fruits, etc.) via the phloem. However, soil uptake entails metal transport from the roots to the aerial parts via the xylem system. Therefore, the type of application may have different effects on the metal distribution at the tissue and cellular levels in the plants [55].

\subsection{Dry Weight and Total Phenolic Contents}

Table 6 shows the effect of SPs and Cu NPs on the dry biomass of wheat in both foliar and soil applications, respectively. Clearly, the dry biomass increased significantly with an increasing concentration of SPs to $0.06 \mathrm{mg} / \mathrm{mL}$, thus recording 0.78 and $0.56 \mathrm{~g} /$ plant in foliar and soil applications, respectively. The same stimulant effect was reported for seaweed extracts on sunflowers [56].

Table 6. Effect of SPs and Cu NPs on the dry weight of wheat in foliar and soil applications.

\begin{tabular}{ccccc}
\hline \multirow{2}{*}{$\begin{array}{c}\text { Concentration } \\
\text { mg m } \mathbf{L}^{-\mathbf{1}}\end{array}$} & \multicolumn{2}{c}{ DW Foliar Application (g) } & \multicolumn{2}{c}{ DW Soil Application (g) } \\
\cline { 2 - 5 } & SPs & Cu NPs & SPs & Cu NPs \\
\hline 0 & $0.49^{\mathrm{b}} \pm 0.06$ & $0.49^{\mathrm{b}} \pm 0.06$ & $0.33^{\mathrm{bc}} \pm 0.14$ & $0.33^{\mathrm{bc}} \pm 0.14$ \\
0.004 & $0.51^{\mathrm{b}} \pm 0.04$ & $0.81^{\mathrm{a}} \pm 0.1$ & $0.19^{\mathrm{ab}} \pm 0.14$ & $0.44^{\mathrm{bc}} \pm 0.11$ \\
0.03 & $0.73^{\mathrm{a}} \pm 0.1$ & $0.66^{\mathrm{ab}} \pm 0.19$ & $0.17^{\mathrm{c}} \pm 0.08$ & $0.31^{\mathrm{abc}} \pm 0.09$ \\
0.06 & $0.78^{\mathrm{a}} \pm 0.14$ & $0.46^{\mathrm{b}} \pm 0.07$ & $0.56^{\mathrm{a}} \pm 0.12$ & $0.34^{\mathrm{ab}} \pm 0.09$ \\
\hline
\end{tabular}

Although a decrease in the total chlorophyll and carotenoids was previously observed after 14 days of application of SPs, yet it can be inferred that the plant overcame this effect after 28 days by producing antioxidants as a defense mechanism. Plants can survive under the oxidative stress of biotic or abiotic SPs by exhibiting adaptive biochemical responses that entail the production of antioxidant compounds or enzymes. Antioxidative defense systems can be nonenzymatic involving, for example, an increase in the total phenolic content, or enzymatic employing peroxidase (POD) and catalase (CAT) enzymes. These defense mechanisms protect plants against oxidative stress damage and enhance its growth $[50,57]$. This hypothesis can be confirmed by inspecting Figure $4 a, b$ which depict the total phenolic content (TPC) of wheat leaves upon exposure to SPs and Cu NPs in foliar and soil applications, respectively. As can be observed in (Figure $4 \mathrm{a}, \mathrm{b}$ ), the TPC significantly increased relative to the control upon increasing the concentration of SPs to $0.06 \mathrm{mg} / \mathrm{L}$, thus recording 16.59 and $8.13 \mathrm{mg} \mathrm{GA} / \mathrm{g}$ in foliar and soil applications, respectively. A positive correlation between antioxidant activity and TPC has been previously reported [21]. 

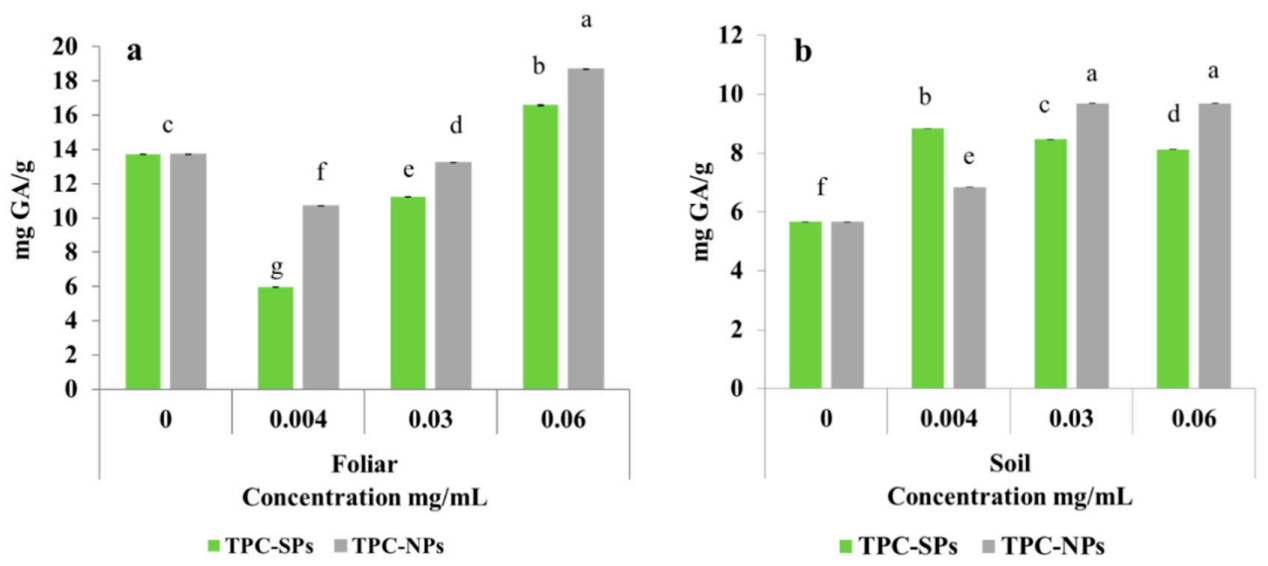

Figure 4. Total phenolic content $(\mathbf{a}, \mathbf{b})$ in wheat leaves upon respective foliar and soil application of SPs and $\mathrm{Cu}$ NPs.

On the other hand, treatment with $\mathrm{Cu}$ NPs showed no effect on the dry weight of wheat plants in both foliar and soil applications. However, it augmented the TPC where the highest contents of 18.69 and 9.69 were obtained upon foliar and soil application of $0.06 \mathrm{mg} / \mathrm{mL}$ of $\mathrm{Cu}$ NPs. The promoting effect of nanoparticles on the total phenolic content was previously observed in Dracocephalum moldavica leaves upon exposure to Ag NPs [50]. Thus, it can be deduced that the plant resisted the inhibition effect of $\mathrm{Cu}$ NPs by producing antioxidants. Consequently, the plant dry weight was maintained via this defense mechanism.

To compare plant growth and development at different time points upon a foliar or soil application with the highest concentration $(0.06 \mathrm{mg} / \mathrm{mL})$ of SPs or Cu NPs, Figure 5 was constructed to show chlorophyll and carotenoids contents after 7 and 14 days of application. In the foliar application after 7 and 14 days, the chlorophyll and carotenoid contents obtained after the $\mathrm{Cu}$ NPs treatment were higher than their counterparts obtained upon SPs treatment. A significant difference, however, was observed with the 14-day application only. Relative to the control, the reduction in chlorophyll and carotenoid contents with $\mathrm{Cu}$ NPs treatment was less than that encountered with SPs treatment. Hence, Cu NPs have less inhibitory effect than that of SPs due to the reasons alluded to earlier. In soil application, SPs also showed significant inhibitory effects, however $\mathrm{Cu}$ NPs significantly stimulated growth after 14 days of application.

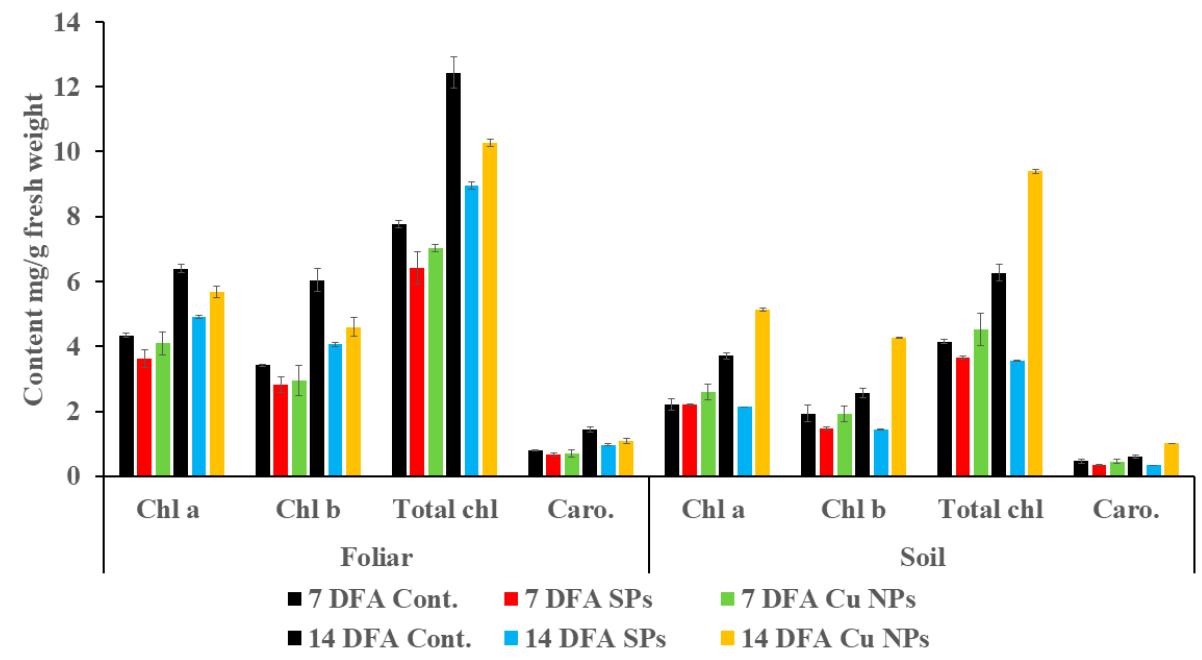

Figure 5. Contents of chlorophyll and carotenoids ( $\mathrm{mg} / \mathrm{g}$ fresh weight) of wheat seedlings treated by $0.06 \mathrm{mg} / \mathrm{L}$ of SPs and Cu NPs after 7 and 14 days from foliar and soil applications. The black bar indicates the control for each measured parameter. 
The effects of $0.06 \mathrm{mg} / \mathrm{L}$ of SPs and Cu NPs on the TPC and the dry weight after 28 days of foliar and soil applications are depicted in Figure 6. Clearly, the treatment with either SPs or Cu NPs enhanced TPC in both applications. On the other hand, the dry weight increased with SPs treatment and was maintained relative to the control in the case of $\mathrm{Cu}$ NPs treatment. This is probably due to the antioxidant defense mechanism undergone by the plant as explained earlier.

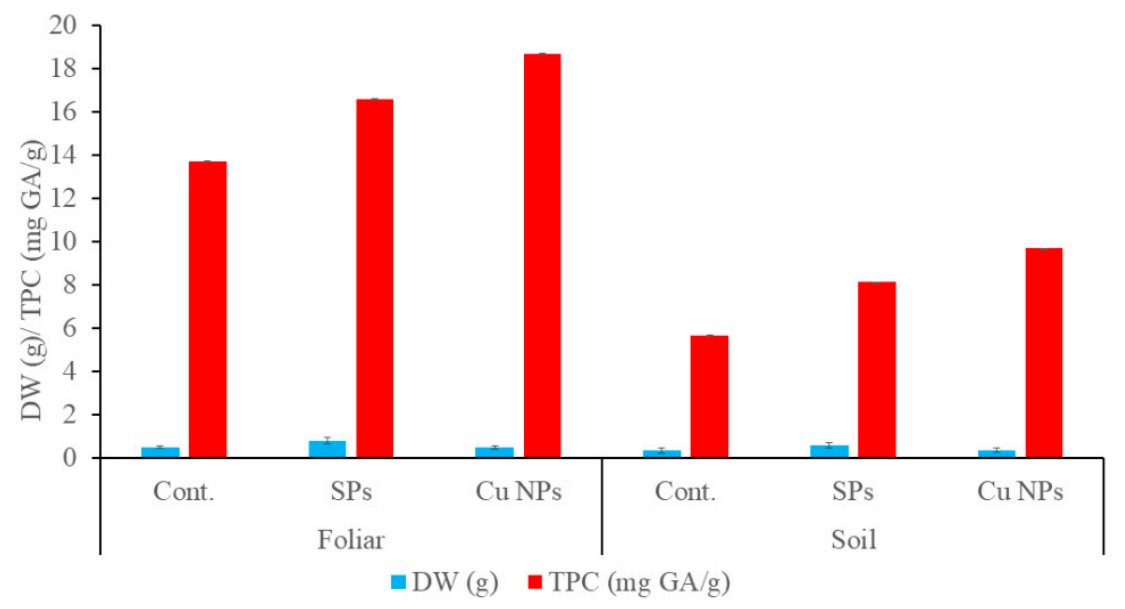

Figure 6. Dry weight and total phenolic content of wheat seedlings treated by $0.06 \mathrm{mg} / \mathrm{L}$ of SPs and Cu NPs after 28 days from foliar and soil applications.

\section{Conclusions}

SPs extracted from mangrove leaves showed an inhibitory effect on the seed germination of wheat seedlings, as well as the total chlorophyll and carotenoids contents in each of the foliar or soil applications. This effect may be owed to the autotoxicity of SPs in mangrove plants which was previously reported [58]. The inhibitory effect of SPs on the total chlorophyll and carotenoids contents observed in the soil application was slightly more pronounced than that obtained in the foliar application. The percent reduction in respective total chlorophyll and carotenoids contents amounted to $43.06 \%$ and $43.33 \%$, respectively, in the soil application, as well as $49.76 \%$ and $70.00 \%$ in the foliar application. Previous work reported the impact of allelopathic interactions on plant growth and showed that it affected the growth of the root more than other vegetation parts of the plant since it influenced the absorption of phenolic compounds [59,60].

On the other hand, $\mathrm{Cu}$ NPs showed inhibitory effects that are slightly less pronounced, or rather comparable, to those of the free SPs extract in both seed germination and foliar applications. Therefore, the nanoformulation of Cu NPs can be as effective as the free SPs in its herbicidal effect. In addition to this, the nanoformulation could offer more advantages than that of free SPs. The nanosized metal holds the capping layer of SPs tightly due to the high surface tension which helps in the controlled release of SPs [61]. Consequently, the nutrients in SPs would potentially be delivered to its specific target sites in the plant [62]. Furthermore, the nanoformulation could increase the bioavailability of soil nutrients to be absorbed by the plant root. The photosynthesis of Spinacia oleracea plants was enhanced when the soil was treated with $\mathrm{CuO} \mathrm{NPs} \mathrm{at} 200 \mathrm{mg} / \mathrm{kg}$ concentration after 60 days of application [63]. Along with the benefits offered by the nanoformulation as an herbicide in seed germination and foliar application, it significantly promoted the total chlorophyll and carotenoids in the soil application. This implies that it can be also utilized as a stimulant in soil applications. The difference in the behavior of $\mathrm{Cu}$ NPs in seed, foliar and soil applications might be attributed to several reasons. Copper nanoparticles were probably more absorbed by leaves than roots since they got adsorbed by soil particles, yet they were not readily transported by the root system [64]. On the contrary, and in seed germination, it was reported that copper nanoparticles can cross the cell membrane and accumulate in the cell until they reach their toxic level [65]. 
Supplementary Materials: The following are available online at http://www.mdpi.com/2076-3417/10/18/6302/s1, Table S1 Constituents of sugars calculated as area percentage from the total chromatogram of HPLC. Figure S1 HPLC chromatogram of SPs.

Author Contributions: Conceptualization, M.M.H.E.-S.; M.S.A.; A.S.M. and H.L.E.; methodology, M.M.H.E.-S.; M.S.A. and A.S.M.; software, A.S.M.; validation, H.L.E., and H.A.G.; formal analysis, M.M.H.E.-S.; investigation, H.L.E. and H.A.G.; data curation, H.A.G.; writing—original draft preparation, H.L.E.; H.A.G.; writing一review and editing, M.M.H.E.-S.; A.S.M.; and M.S.A.; supervision, M.S.A.; M.M.H.E.-S. and A.S.M. All authors read and approved the final manuscript.

Funding: This study was supported by the American University in Cairo (proposal UG\# 1709695).

Acknowledgments: The authors would like to thank the Chemistry Department at the American University in Cairo for conducting the nanoparticle synthesis and characterization experiments as well as the seed germination tests, and the Agriculture Research Center in Cairo for supplying the wheat seeds and for conducting the foliar and soil tests.

Conflicts of Interest: The authors declare no conflict of interest.

\section{References}

1. Vo, T.-S.; Ngo, D.-H.; Kang, K.-H.; Jung, W.-K.; Kim, S.-K. The beneficial properties of marine polysaccharides in alleviation of allergic responses. Mol. Nutr. Food Res. 2014, 59, 129-138. [CrossRef]

2. Percival, E. The polysaccharides of green, red and brown seaweeds: Their basic structure, biosynthesis and function. Br. Phycol. J. 1979, 14, 103-117. [CrossRef]

3. Love, J.; Percival, E. The polysaccharides of the green seaweed Codium fragile. Part III. A $\beta-1,4$-linkedmannan. J. Chem. Soc. 1964, 3345-3350. [CrossRef]

4. Haq, Q.N.; Percival, E. Structural Studies on the Water: Soluble Polysaccharide from the Green Seaweed, Ulva Lactuca. In Some Contemporary Studies in Marine Science; Allen and Unwin: London, UK, 1966; p. 355.

5. Abdel-Fattah, A.F.; Hussien, M.M.; Salem, M.M. Studies of the purification and some properties of sargassan, as sulphated hetero-polysaccharides from Sargassum linifolium. Carbohydr. Res. 1974, 33, 9-17. [CrossRef]

6. Shi, Y.; Sheng, J.; Yang, F.; Hu, Q. Food Chemistry Purification and identification of polysaccharide derived from Chlorella pyrenoidosa. Food Chem. 2007, 103, 101-105. [CrossRef]

7. Essa, H.; Fleita, D.; Rifaat, D.; Samy, S.; El-Sayed, M. Towards optimizing the conventional and ultrasonic-assisted extraction of sulfated polysaccharides from marine algae. IOP Conf. Ser. Mater. Sci. Eng. 2018, 464, 1-11. [CrossRef]

8. Denancé, N.; Sánchez-Vallet, A.; Goffner, D.; Molina, A. Disease resistance or growth: The role of plant hormones in balancing immune responses and fitness costs. Front. Plant Sci. 2013, 4, 1-12. [CrossRef]

9. Yuan, T.T.; Xu, H.H.; Zhang, K.X.; Guo, T.T.; Lu, Y.T. Glucose inhibits root meristem growth via ABA Insensitive 5, which represses PIN1 accumulation and auxin activity in Arabidopsis. Plant Cell Environ. 2014, 37, 1338-1350. [CrossRef]

10. Perrino, E.V.; Calabrese, G. Endangered segetal species in southern Italy: Distribution, conservation status, trends, actions and ethnobotanical notes. Genet. Resour. Crop Evol. 2018, 65, 2107-2134. [CrossRef]

11. Perrino, E.V.; Perrino, P. Crop wild relatives: Know how past and present to improve future research, conservation and utilization strategies, especially in Italy: A review. Genet. Resour. Crop Evol. 2020, 67, 1067-1105. [CrossRef]

12. Arya, A.; Gupta, K.; Chundawat, T.S.; Vaya, D. Biogenic Synthesis of Copper and Silver Nanoparticles Using Green Alga Botryococcus braunii and Its Antimicrobial Activity. Bioinorg. Chem. Appl. 2018. [CrossRef] [PubMed]

13. Abboud, Y.; Saffaj, T.; Chagraoui, A.; El Bouari, A.; Brouzi, K.; Tanane, O.; Ihssane, B. Biosynthesis, characterization and antimicrobial activity of copper oxide nanoparticles (CONPs) produced using brown alga extract (Bifurcaria bifurcata). Appl. Nanosci. 2014, 4, 571-576. [CrossRef]

14. Ramaswamy, S.V.P.; Narendhran, S.; Sivaraj, R. Potentiating effect of ecofriendly synthesis of copper oxide nanoparticles using brown alga: Antimicrobial and anticancer activities. Bull. Mater. Sci. 2016, 39, 361-364. [CrossRef]

15. Moon, Y.S.; Park, E.S.; Kim, T.O.; Lee, H.S.; Lee, S.E. SELDI-TOF MS-based discovery of a biomarker in Cucumis sativus seeds exposed to $\mathrm{CuO}$ nanoparticles. Environ. Toxicol. Pharmacol. 2014, 38, 922-931. [CrossRef] [PubMed] 
16. Da Costa, M.V.J.; Sharma, P.K. Effect of copper oxide nanoparticles on growth, morphology, photosynthesis, and antioxidant response in Oryza sativa. Photosynthetica 2016, 54, 110-119. [CrossRef]

17. Duran, N.M.; Savassa, S.M.; Lima, R.G.; De Almeida, E.; De Linhares, F.S.; Van Gestel, C.A.M.; De Pereira Carvalho, H.W. X-ray Spectroscopy Uncovering the Effects of Cu Based Nanoparticle Concentration and Structure on Phaseolus vulgaris Germination and Seedling Development. J. Agric. Food Chem. 2017, 65, 7874-7884. [CrossRef]

18. Chrums, S.C.; Stephen, A.M. The determination of molecular weight distribution of maize starch dextrins by gel chromatography. J. S. Afr. Chem. Inst. 1973, 26, 46-50.

19. Chen, Y.; Mao, W.; Wang, B.; Zhou, L.; Gu, Q.; Chen, Y.; Zhao, C.; Lia, N.; Wang, C.; Shan, J.; et al. Preparation and characterization of an extracellular polysaccharide produced by the deep-sea fungus Penicillium griseofulvum. Bioresour. Technol. 2013, 132, 178-181. [CrossRef]

20. Saifuddin, C.; Nian, L.; Ning, K. Chitosan-silver Nanoparticles Composite as Point-of-use Drinking Water Filtration System for Household to Remove Pesticides in Water. Asian J. Biochem. 2011, 6, 142-159. [CrossRef]

21. Fleita, D.; El-Sayed, M.; Rifaat, D. Evaluation of the antioxidant activity of enzymatically-hydrolyzed sulfated polysaccharides extracted from red algae; Pterocladia capillacea. LWT Food Sci. Technol. 2015, 63, 1236-1244. [CrossRef]

22. El-Sayed, M.; Fleita, D.; Rifaat, D.; Essa, H. Assessment of the State-of the-Art Developments in the Extraction of Antioxidants From Marine Algal Species. In Ingredients Extraction by Physicochemical Methods in Food; Academic Press: London, UK, 2017; pp. 367-397.

23. El Azm, N.A.; Fleita, D.; Rifaat, D.; Mpingirika, E.Z.; Amleh, A.; El-Sayed, M.M.H. Production of bioactive compounds from the sulfated polysaccharides extracts of ulva lactuca: Post-extraction enzymatic hydrolysis followed by ion-exchange chromatographic fractionation. Molecules 2019, 24, 2132. [CrossRef] [PubMed]

24. ATSM American Society for Testing. Materials Standard Guide for Conducting Terrestrial Plant Toxicity Tests; ASTM International: West Conshohocken, PA, USA, 2003.

25. Ancuţa, D.; Renata, S.; Carmen, B.; Şumălan, R. Seed germination and seedling growth of tomato as affected by different types of compost water extracts. J. Hortic. For. Biotechnol. 2013, 17, 155-160.

26. Dezfuli, P.M.; Sharif-zadeh, F.; Janmohammadi, M. Influence Of Priming Techniques On Seed Germination Behavior of Maize Inbred Lines (Zea Mays L.). ARPN J. Agric. Biol. Sci. 2008, 3, 22-25.

27. Hiscox, J.D.; Israelstam, G.F. A method for the extraction of chlorophyll from leaf tissue without maceration. Can. J. Bot. 1979, 57, 1332-1334. [CrossRef]

28. Arnon, D.I. Copper enzymes in isolated chloroplasts, polyphenoloxidase in Beta vulgaris. Plant Physiol. 1949, 24, 1-15. [CrossRef] [PubMed]

29. Cañal, V.M.J.; Fernandez, B.M.; Sanchez, R.T. Effect of glyphosate on growth and the chlorophyll and carotenoid levels of yellow Nutsedge (Cyperus esculentus). Weed Sci. 1985, 33, 751-754.

30. Caroling, G.; Vinodhini, E.; Ranjitham, A.M.; Shanthi, P. Biosynthesis of Copper Nanoparticles Using Aqueous Phyllanthus Embilica (Gooseberry) Extract-Characterisation and Study of Antimicrobial Effects. Int. J. Nanomater. Chem. 2015, 1, 253-263.

31. Shaikh, R.R.; Mirza, S.S.; Sawant, M.R.; Dare, S.B. Biosynthesis of Copper Nanoparticles using Vitis vinifera Leaf Extract and Its Antimicrobial Activity. Pharm. Lett. 2016, 8, 265-272.

32. Roy, K.; Sarkar, C.K.; Ghosh, C.K. Antibacterial mechanism of biogenic copper nanoparticles synthesized using Heliconia psittacorum leaf extract. Nanotechnol. Rev. 2016, 5, 529-536. [CrossRef]

33. Gopalakrishnan, K.; Ramesh, C.; Ragunathan, V.; Thamilselvan, M. antibacterial activity of $\mathrm{Cu}_{2} \mathrm{O}$ Nanoparticles on E.coli synthesized fromtridax procumbens leaf extract and surface coating with polyaniline. Dig. J. Nanomater. Biostruct. 2012, 7, 833-839.

34. El-Rafie, H.M.; El-Rafie, M.H.; Zahran, M.K. Green synthesis of silver nanoparticles using polysaccharides extracted from marine macro algae. Carbohydr. Polym. 2013, 96, 403-410. [CrossRef] [PubMed]

35. Ananthi, S.; Balaji Raghavendran, H.R.; Sunil, A.; Gayathri, V.; Ramakrishnan, G.; Vasanthi, H.R. In vitro antioxidant and in vivo anti-inflammatory potential of crude polysaccharide from Turbinaria ornata (Marine Brown Alga). Food Chem. Toxicol. 2010, 48, 187-192. [CrossRef] [PubMed]

36. Yin, L.; Colman, B.P.; McGill, B.M.; Wright, J.P.; Bernhardt, E.S. Effects of Silver Nanoparticle Exposure on Germination and Early Growth of Eleven Wetland Plants. PLoS ONE 2012, 7, e47674. [CrossRef]

37. Hafeez, A.; Razzaq, A.; Mahmood, T.; Jhanzab, H.M. Potential of Copper Nanoparticles to Increase Growth and Yield of Wheat. J. Nanosci. Adv. Technol. 2015, 1, 6-11. 
38. Yasmeen, F.; Razzaq, A.; Iqbal, M.N.; Jhanzab, H.M. Effect of silver, copper and iron nanoparticles on wheat germination. Int. J. Biosci. 2015, 6, 112-117. [CrossRef]

39. Lin, D.; Xing, B. Phytotoxicity of nanoparticles: Inhibition of seed germination and root growth. Environ. Pollut. 2007, 150, 243-250. [CrossRef]

40. Gibson, S.I. Control of plant development and gene expression by sugar signaling. Curr. Opin. Plant Biol. 2005, 8, 93-102. [CrossRef]

41. Finkelstein, R.R.; Lynch, T.J. Abscisic acid inhibition of radicle emergence but not seedling growth is suppressed by sugars. Plant Physiol. 2005, 122, 1179-1186. [CrossRef]

42. Rook, F.; Hadingham, S.A.; Li, Y.; Bevan, M.W. Sugar and ABA response pathways and the control of gene expression. Plant Cell Environ. 2006, 29, 426-434. [CrossRef]

43. Bentsink, L.; Koornneef, M. Seed dormancy and germination. In The Arabidopsis Book; Somerville, C.R., Meyerowitz, E.M., Eds.; American Society of Plant Biologists: Rockville, MD, USA, 2002.

44. Koornneef, M.; Karssen, C.M. Seed dormancy and germination. In Arabidopsis; Cold Spring Harbor Laboratory Press: Cold Spring Harbor, NY, USA, 1994; pp. 313-334.

45. Nair, P.M.G.; Chung, I.M. Impact of copper oxide nanoparticles exposure on Arabidopsis thaliana growth, root system development, root lignificaion, and molecular level changes. Environ. Sci. Pollut. Res. 2014, 21, 12709-12722. [CrossRef]

46. Shi, J.; Peng, C.; Yang, Y.; Yang, J.; Zhang, H.; Yuan, X.; Chen, Y.; Hu, T. Phytotoxicity and accumulation of copper oxide nanoparticles to the Cu-tolerant plant Elsholtzia splendens. Nanotoxicology 2014, 8, 179-188. [CrossRef] [PubMed]

47. AlQuraidi, A.; Mosa, K.; Ramamoorthy, K. Phytotoxic and Genotoxic Effects of Copper Nanoparticles in Coriander (Coriandrum sativum-Apiaceae). Plants 2019, 8, 19. [CrossRef] [PubMed]

48. Mazumdar, H. The Impact of Silver Nanoparticles on Plant Biomass and Chlorophyll Content. Res. Inven. Int. J. Eng. Sci. 2014, 4, 2319-6483.

49. Qian, H.; Peng, X.; Han, X.; Ren, J.; Sun, L.; Fu, Z. Comparison of the toxicity of silver nanoparticles and silver ions on the growth of terrestrial plant model Arabidopsis thaliana. J. Environ. Sci. 2013, 25, 1947-1956. [CrossRef]

50. Pak, Z.H.; Abbaspour, H.; Karimi, N. Effects of silver nanoparticle exposure on growth, physiological and biochemical parameters of dracocephalum moldavica L. Iran J. Plant Physiol. 2017, 7, 2173-2183. [CrossRef]

51. Vishwakarma, K.; Shweta; Upadhyay, N.; Singh, J.; Liu, S.; Singh, V.P.; Prasad, S.M.; Chauhan, D.K.; Tripathi, D.K.; Sharma, S. Differential Phytotoxic Impact of Plant Mediated Silver Nanoparticles (AgNPs) and Silver Nitrate $\left(\mathrm{AgNO}_{3}\right)$ on Brassica sp. Front. Plant Sci. 2017, 8, 1-12. [CrossRef]

52. Sharif, F.; Westerhoff, P.; Herckes, P. Sorption of trace organics and engineered nanomaterials onto wetland plant material. Environ. Sci. Process. Impacts 2013, 15, 267-274. [CrossRef]

53. Pola, M.; Tamara, L.C.; Andrew, T.H. Toxicity, uptake, and translocation of engineered nanomaterials in vascular plants. Environ. Sci. Technol. 2012, 46, 9224-9239.

54. Plaksenkova, I.; Jermal,onoka, M.; Bankovska, L.; Gavarāne, I.; Gerbreders, V.; Sledevskis, E.; Snikeris, J.; Kokina, I. Effects of $\mathrm{Fe}_{3} \mathrm{O}_{4}$ Nanoparticle Stress on the Growth and Development of Rocket Eruca sativa. J. Nanomater. 2019, 2019, 2678247. [CrossRef]

55. Wang, Z.; Xie, X.; Zhao, J.; Liu, X.; Feng, W.; White, J.C.; Xing, B. Xylem and phloem-based transport of CuO nanoparticles in maize (Zea mays L.). Environ. Sci. Technol. 2012, 46, 4434-4441. [CrossRef]

56. Salama, A.; Salama, A. The Effect of Foliar Spray with Cyanobacterial Extracts on Growth, Yield and Quality of Lettuce Plants (Lactuca sativa L.). Middle East J. Agric. Res. 2016, 5, 90-96.

57. Zou, P.; Lu, X.; Zhao, H.; Yuan, Y.; Meng, L.; Zhang, C.; Li, Y. Polysaccharides Derived from the Brown Algae Lessonia nigrescens Enhance Salt Stress Tolerance to Wheat Seedlings by Enhancing the Antioxidant System and Modulating Intracellular Ion Concentration. Front. Plant Sci. 2019, 10, 48. [CrossRef] [PubMed]

58. Nazim, K.; Ahmed, M.; Shaukat, S.S.; Khan, M.U.; Hussian, S.S. Auto Toxicity of Avicennia Marina (Forsk.) Vierh In Pakistan. Pak. J. Bot. 2014, 46, 465-470.

59. White, R.H.; Douglas, W.; Udo, B. Allelopathic potential of legume debris and aqueous extracts. Weed Sci. 1989, 37, 674-679. [CrossRef]

60. Winter, A.G. New physiological and biological aspects in the interrelationships between higher plants. In Mechanisms in Biologkal Competition; Academic Press: New York, NY, USA, 1961; pp. 229-244. 
61. Brady, N.R.; Weil, R.R. The Nature and Properties of Soils; Prentice Hall: Upper Saddle River, NJ, USA, 1999; pp. $415-473$.

62. Sasson, Y.; Levy-Ruso, G.; Toledano, O.; Ishaaya, I. Nanosuspensions: Emerging novel agrochemical formulations. In Insecticides Design Using Advanced Technologies; Springer: Berlin, Germany, 2007; pp. 1-39.

63. Wang, Y.; Lin, Y.; Xu, Y.; Yin, Y.; Guo, H.; Du, W. Divergence in response of lettuce (var. ramosa Hort.) to copper oxide nanoparticles/microparticles as potential agricultural fertilizer. Environ. Pollut. Bioavailab. 2019, 31, 80-84. [CrossRef]

64. Taiz, L.; Zeiger, E. (Eds.) Plant Physiology, 5th ed.; Sinauer Associates Inc.: Sunderland, MA, USA, $2020 ;$ p. 781.

65. Lee, W.; An, Y.J.; Yoon, H.; Kweon, H.S. Toxicity and bioavailability of copper nanoparticles to the terrestrial plants mung bean (Phaseolus radiatus) and wheat (Triticum aestivum): Plant agar test for water-insoluble nanoparticles. Environ. Toxicol. Chem. 2008, 27, 1915-1921. [CrossRef] [PubMed]

(C) 2020 by the authors. Licensee MDPI, Basel, Switzerland. This article is an open access article distributed under the terms and conditions of the Creative Commons Attribution (CC BY) license (http://creativecommons.org/licenses/by/4.0/). 